\title{
GRIYA MODE BERKELANJUTAN DI KOTA BEKASI
}

\author{
Muhammad Dzamarsyach Dewanto ${ }^{1)}$, Diah Anggraini ${ }^{2)}$ \\ 1)Program Studi S1 Arsitektur, Fakultas Teknik, Universitas Tarumanagara, dzamarsyach@gmail.com \\ 2) Program Studi S1 Arsitektur, Fakultas Teknik, Universitas Tarumanagara, diaha@ft.untar.ac.id
}

Masuk: 04-07-2021, revisi: 14-08-2021, diterima untuk diterbitkan: 23-10-2021

\begin{abstract}
Abstrak
Meningkatnya konsumsi pakaian setiap tahunnya melahirkan konsep baru yaitu fast fashion. Ini adalah sebuah istilah modern untuk pakaian murah dan trendi yang mengambil ide mode dari peragaan busana atau gaya modis dari selebriti. Sistem kerja fast fashion dikenal sebagai proses masal yang mampu menghasilkan pakaian dengan cepat. Akan tetapi, proses ini menggunakan sumber daya alam yang terlalu banyak dan merugikan lingkungan. Padahal hasil kain yang dihasilkan tidak sebanding dengan alam yang dikorbankan. Konsep fast fashion yang harusnya mampu menyelaraskan produksi dan konsumennya akan kehilangan keseimbangan. Proyek ini memiliki tujuan untuk membangun sebuah karya arsitektur yang mampu mengurangi dampak negatif industri fesyen terhadap pencemaran lingkungan. Mengajak masyarakat untuk berpartisipasi dalam mengubah budaya yang konsumtif dan hedonisme. Sehingga menciptakan sebuah komunitas yang sadar akan gaya hidup yang lebih baik untuk menjadi generasi yang produktif dan sirkular dalam konsumsi fesyen. Dalam perancangannya digunakan metode Behaviorology Strategy milik Atelier Bow-Wow yang mempelajari konteks kepedulian terhadap lingkungan, sosial dan ekonomi yang berusaha mengubah masalah menjadi peluang sebagai aspek dasar dalam desain yang ramah akan ekologi. Studi ini juga menggunakan metode Nonidentity- programming oleh Bernard Tschumi untuk menciptakan program dalam karya arsitektur yang sirkular, dan metode parametrik dalam perencanaan desain bangunan fasadnya. Diharapkan proyek ini mampu dalam menghadapi persoalan krisis lingkungan akibat praktek industri fesyen demi menciptakan kehidupan yang berkesinambungan.
\end{abstract}

\section{Kata kunci: berkelanjutan, fesyen/mode, gaya hidup, lingkungan}

\begin{abstract}
The increasing consumption of clothing every year gives birth to a new concept, namely fast fashion. It is a modern term for cheap and trendy clothes that take fashion ideas from fashion shows or fashionable styles from celebrities. The fast fashion work system is known as a mass process that is able to produce clothes quickly. However, this process uses too many natural resources and is detrimental to the environment. Even though the results of the fabric produced are not comparable to the nature that was sacrificed. The concept of fast fashion which should be able to harmonize production and consumers will lose balance. This project has a goal to build an architectural masterpiece that can reduce the negative impact of the fashion industry on environmental pollution. Inviting the public to participate in changing a consumptive and hedonistic culture. Thus creating a community that is aware of a better lifestyle to become a productive and circular generation in fashion consumption. In its design, Atelier Bow-Wow's Behaviorology Strategy method is used which studies the context of environmental, social and economic concerns that seek to turn problems into opportunities as a basic aspect of eco-friendly design. This study also uses the Nonidentity-programming method by Bernard Tschumi to create programs in circular architectural works, and parametric methods in planning the design of the building's facade. It is hoped that this project will be able to deal with the environmental crisis caused by the practice of the fashion industry in order to create a sustainable life.
\end{abstract}

Keywords: sustainable, fashion, lifestyle, environment 


\section{PENDAHULUAN}

\section{Latar Belakang}

Fast fashion merupakan cara bisnis industri fesyen yang memproduksi pakaian dengan jumlah banyak dan cepat demi memenuhi permintaan pasar. Kemunculan fast fashion mendukung gaya hidup konsumtif karena harganya yang relatif lebih murah dibandingkan pakaian karya designer. Harganya yang terjangkau dan desain yang modis menjadi daya tarik tersendiri yang membuat bisnis ini digemari konsumen untuk terus mengikuti tren mode.

Pemilik industri fesyen di negara maju memilih membuka pabriknya di negara berkembang seperti Vietnam, Filipina, Pakistan, Indonesia, dan negara perkembang lainnya. Negaranegara ini tidak memiliki bahan mentah yang dibutuhkan dan harus didatangkan dari negara lain seperti Cina, Amerika Serikat dan India. Setelah produksi selesai, pakaian akan dikirim ke seluruh penjuru dunia. Maka dari itu, bisnis fast fashion menjadi populer dan semakin berkembang di seluruh dunia. Globalisasi memberi peluang beberapa merek ternama dalam industri ini dapat merambah bisnis retail busana di berbagai negara. Sementara itu di Indonesia produk lokal dalam industri fesyen juga masuk ke pasar retail pakaian jadi misalnya produk busana muslim.

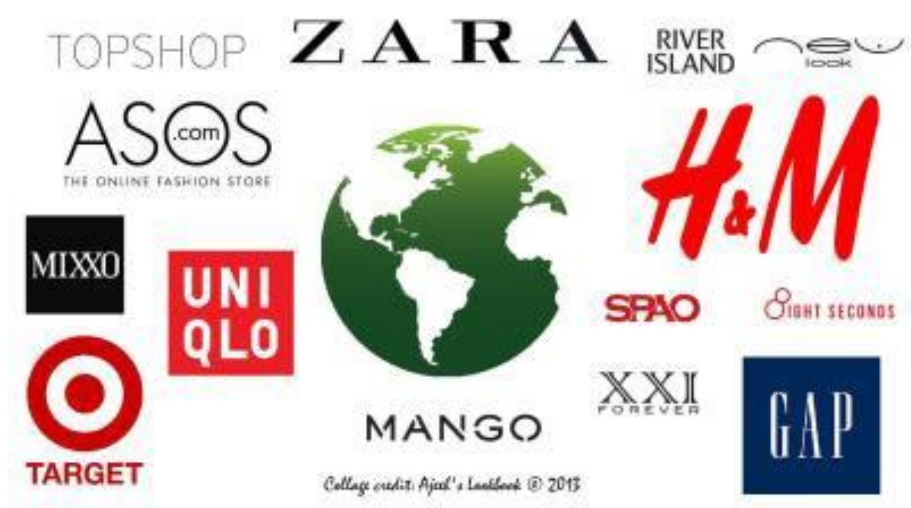

Gambar 1. Brand Retailer fast fashion

Sumber: https://www.trustedclothes.com/blog/wp-

content/uploads/2016/06/fastfashion.jpg

\section{Rumusan Permasalahan}

a. Industri fast fesyen mempunyai dampak negatif terhadap upaya pelestarian lingkungan hidup. Apakah melalui arsitektur dapat diciptakan suatu wadah aktivitas masyarakat penggiat dan konsumen fesyen (griya mode) yang dapat mengurangi dampak negatif industri fesyen terhadap pencemaran lingkungan.

b. Bagaimana menghasilkan konsep perancangan suatu griya mode yang berkelanjutan, dan mampu menumbuhkan kesadaran masyarakat demi mewujudkan sistem sirkular fesyen yang lebih baik dan berkelanjutan.

\section{Tujuan}

Menciptakan proyek arsitektur yang mampu mewadahi kebutuhan dan gaya hidup masyarakat dalam konsumsi fesyen masa kini. Dengan harapan mampu menumbuhkan rasa kesadaran masyarakat demi mewujudkan sistem sirkular fesyen yang lebih baik dan berkelanjutan. Sehingga dapat mengurangi dampak kerusakan dan penumpukan limbah terhadap alam sekitar. 


\section{Sasaran}

Proyek ini ditujukan untuk masyarakat khususnya di Kota Bekasi dan sekitarnya. Bekasi merupakan kota besar yang mempunyai berbagai pusat perbelanjaan besar yang selalu ramai karena budaya konsumtif masyarakatnya. Selain itu pertumbuhan kegiatan industri fesyen juga terjadi di Kota Bekasi dan sekitarnya. Praktik industri fast fashion yang menggunakan sumber daya alam berlebih dan menghasilkan limbah pencemar yang besar, juga telah menyebabkan terganggunya kualitas lingkungan hidup di kota tersebut.

\section{KAJIAN LITERATUR}

\section{Pengertian Ekologi}

Diciptakan oleh ahli zoologi Jerman, Ernst Haeckel (1866) untuk menggambarkan "ekonomi" dari bentuk kehidupan. Berasal dari kata oikos + logi yang memiliki arti ilmu tentang rumah (oikos). Ekologi dapat diartikan sebagai sebuah rumah/oikos yang melakukan dan mendapatkan hasil dari transaksi serta negosiasi terhadap kondisi lingkungan yang dihadapinya.

Dalam catatan dari Stanford Encyclopedia of Philsophy dijelaskan bahwa ada dua masalah penting ketika dihadapkan dalam diskursus ekologi, yaitu :

a. Masalah kompleksitas yaitu membicarakan masalah ekologi dihadapkan bukan hanya pada masalah yang rumit tetapi memilki kompleksitas tinggi. Kondisi rumit dan kompleks ini disebabkan karena menyangkut tentang hubungan antara manusia dengan kondisi alam yang memiliki kedinamisan dalam perubahannya.

b. Masalah keunikan yaitu sistem ekologi dianggap unik baik karena merupakan entitas historis yang bergantung, dan secara struktural karena kompleksitasnya. Kompleksitas dan keunikan dari sebuah kondisi ekosistem menjadi kata kunci dalam menghasilkan kajian keruangan baru bagi bumi ini.

Metode perancangan arsitektur berbasis ekologi, mengidentifikasi potensi dan kendala iklim tropis dalam perancangan pembangunan dan menentukan unsur pendekatan analisis berbasis ekologis yang dapat disistematiskan sebagai strategi metode desain pembangunan berkelanjutan dalam pengelolaan atau manajemen iklim untuk mencapai konservasi dan pelestarian alam di iklim tropis (Kompas.com, 2021).

\section{Konsep Arsitektur Berkelanjutan}

Sebuah konsep arsitektur dapat dikatakan sebagai arsitektur yang berkelanjutan apabila konsep arsitektur tersebut dapat memenuhi kebutuhan penggunanya pada masa sekarang, tanpa membahayakan kemampuan generasi selanjutnya untuk memenuhi kebutuhan hidupnya (Steele, 1997). Terkait dengan hal tersebut, di Indonesia terdapat suatu lembaga yang membantu Pemerintah untuk memberikan konsultasi agar setiap bangunan yang didirikan telah sesuai dengan prinsip bangunan berkelanjutan yaitu Green Building Council Indonesia atau biasa disingkat $\mathrm{GBCl}$. $\mathrm{GBCl}$ merupakan sebuah lembaga independen yang berkomitmen terhadap pendidikan masyarakat dalam mengaplikasikan praktik-praktik lingkungan dan memfasilitasi transformasi industri bangunan yang berkelanjutan. $G B C l$ memiliki tujuan untuk melakukan transformasi dan diseminasi kepada masyarakat dan pelaku bangunan untuk menerapkan prinsip-prinsip bangunan hijau, khususnya di sektor industri bangunan gedung di Indonesia.

\section{Fesyen Berkelanjutan}

Pada tahun 1987 Komisi Pembangunan Lingkungan Dunia memperkenalkan istilah berkelanjutan dengan penjelasan bahwa pembangunan berkelanjutan adalah pembangunan yang memenuhi kebutuhan generasi sekarang tanpa mengurangi kemampuan generasi mendatang untuk memenuhi kebutuhan mereka (Berfield, 2015). Dari sudut pandang yang lebih luas, keberlanjutan dipahami sebagai upaya untuk menjaga dan melestarikan 
keseimbangan lingkungan ekologis, peduli sosial dan budaya, dan upaya untuk bertindak secara etis kepada para pekerjanya. Ketiga pilar ini yang menjadi fokus dari fesyen berkelanjutan. Sejalan dengan meningkat dan berkembang pesatnya industri fesyen berkelanjutan serta semakin jelasnya tujuan dan arah perkembangannya, ternyata masih banyak tantangan dan permasalahan yang perlu dicermati untuk menentukan hasil akhir dan keberhasilan industri ini. Metode untuk mencapai keberhasilan fesyen berkelanjutan belum diklasifikasi dan dijabarkan dengan jelas, mengingat kompleksitas yang ada. Diperlukan adanya suatu upaya yang terintegrasi dan mampu mengkaitkan segala bentuk idealisme dan realita praktikal yang mampu membuat industri ini secara produk dan ekonomi mampu mencapai keberlajutan (Aako \& Koskennurmi-Sivonen, 2013).

\section{TINJAUAN TEORI DESAIN}

\section{Beyond Ecology Architecture}

Beyond Ecology diartikan sebagai sebuah usaha untuk mempelajari suatu kondisi terkini dari suatu ekosistem yang saat ini sedang terjadi dengan mempertimbangkan potensi arsitektur dalam menghasilkan suatu karya yang indah dan berguna untuk masyarakat. Dalam konteks ini, muncul ajakan untuk melampui ekologi melalui arsitektur untuk melakukan spekulasi dan spatialitas dari ekosistem yang sedang dirasakan di dunia. Aspek ini ternyata dilihat juga dari kualitas spasial dengan menempatkan posisi kompleksitas dan keunikan dari ekosistem yang ada di sekitarnya ( Sutanto, 2021).

\section{Transprogramming Architecture}

Transprogramming merupakan sebuah teori yang dikembangkan oleh Bernard Tshumi yang berasal dari pemahaman dekonstruksi. Dekonstruksi \& transprogramming bukan merupakan pendekatan seperti pendekatan arsitektur hijau, berkelanjutan, atau tropis yang berupa penerapan aturan yang ada untuk diterapkan pada desain. Akan tetapi, merupakan suatu teori atau cara yang memberikan keleluasaan dengan cara membongkar aturan, pedoman lama dan memberi kesempatan kepada pengguna untuk mengembangkan pemikiran-pemikiran baru.

Dalam metode ini memungkinkan untuk menggabungkan 2-3 program kegiatan atau lebih menjadi sebuah bentuk yang memiliki keterikatan/hubungan erat. Metode ini cocok dengan konsep fashion design yang setiap ruangnya harus memiliki fungsi atau arti yang berkaitan. Dalam penyusunan program seperti ini juga diharapkan mampu memdorong masyarakat untuk sadar akan pentingnya sircular fashion system.

\section{Concept, Context, dan Content.}

Teori concept, context, content, dan hubunganya memberikan penjelasan bahwa concept desain dapat dihasilkan dari context nya atau content nya. Tidak masalah jika hubungan concept, content, dan context saling timbal balik (reciprocity), berkonflik (conflict), atau saling mengabaikan (indifference). Teori ini memperluas pemikiran aliran modern yang cenderung menekankan pada hubungan timbal balik antara concept, context, dan content. Pada akhirnya pemikiran ini akan menghasilkan suatu peluang untuk menghasilkan ide/konsep yang baru, lebih beragam, dan luas (Tschumi, 2005). Ada beberapa aspek yang harus terpenuhi dalam kaitanya dengan teori Bernard Tschumi ini, aspek tersebut yaitu: aktivitas harus bias tumpeng tindih. bangunan harus mampu beradaptasi dengan program yang berbeda dari waktu ke waktu. Bernard Tschumi menekankan dalam kaitanya dengan teori yang dia ungkapkan bahwa seseorang mungkin melanggar aturan tetapi jangan pernah mengorbankan konsep.

\section{METODE PENELITIAN}

Studi ini menggunakan metode penelitian deskriptif kualitatif dalam proses pengumpulan, interpretasi dan analisis data lapangan yang terdiri dari data sosial, budaya, ekonomi 
masyarkat di lokasi studi, maupun hasil investigasi terhadap kondisi fisik lingkungna pada tapak terpilih. Hasil pembahasan dan analisis digunakan sebagai pertimbangan dalam proses penyusunan konsep perancangan bangunan Griya Mode terutama yang terkait dengan pengolahan tapak, penyusunan program aktivitas dan program ruangnya.

Pengolahan konfigurasi ruang dan kualitas ruang mengacu pada pendekatan transprograming yang mengombinasikan kegiatan penjualan produk, pameran, pengelolaan pakaian bekas, edukasi dan kegiatan komunitas fesyen dalam bangunan.

\section{Investigasi kawasan}

Kawasan sekitar tapak merupakan bagian dari Metropolitan Jabodetabek dan menjadi kota satelit dengan tingkat kepadatan penduduk yang relatif tinggi. Saat ini Kota Bekasi berkembang menjadi tempat tinggal kaum urban dan menjadi sentra industri penting di Jawa Barat. Sebagian besar pusat kota Bekasi merupakan kawasan perbelanjaan yang ramai dan beragam, mulai dari belanja bahan pokok makanan, otomotif, elektronik, dan fesyen yang terus berkembang mengikuti tren.

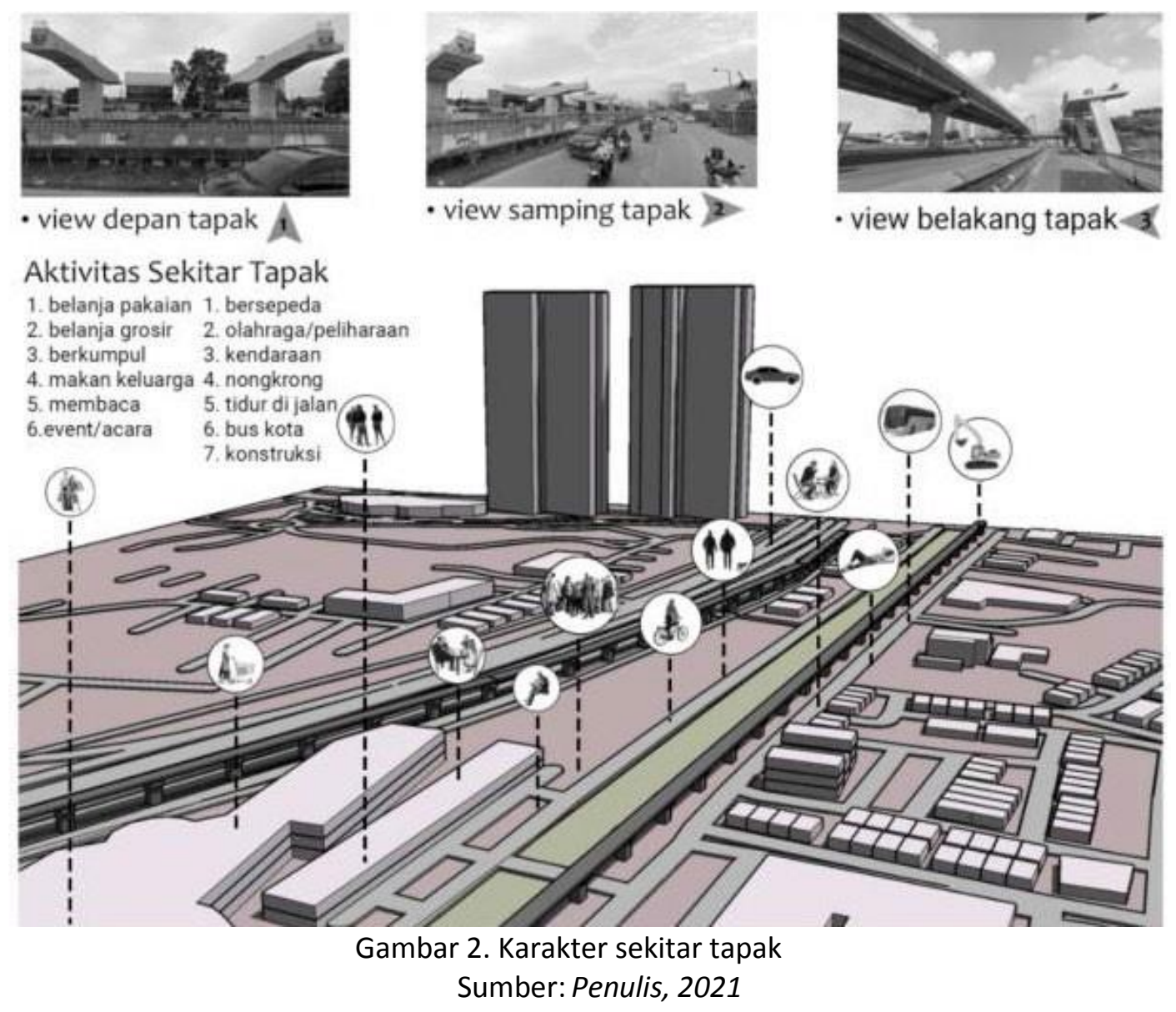

\section{DISKUSI DAN HASIL}

\section{Analisis Tapak}

Tapak yang diusulkan dalam studi ini berada di J;. KH. Noer Ali Bekasi Selatan, Kota Bekasi yang merupakan lokasi berdekatan dengan beberapa pusat perbelanjaan besar. Mengacu pada hasil analisis SWOT (Tabel 1), dapat disimpulkan bahwa potensi lingkungan sekitar tapak memberikan peluang pada berhasilnya proyek ini namun juga memerlukan pertimbangan matang terhadap permasalahan pada tapak (polusi, banyaknya kompetitor, kemudahan akses ke tapak dan sebagainya). 


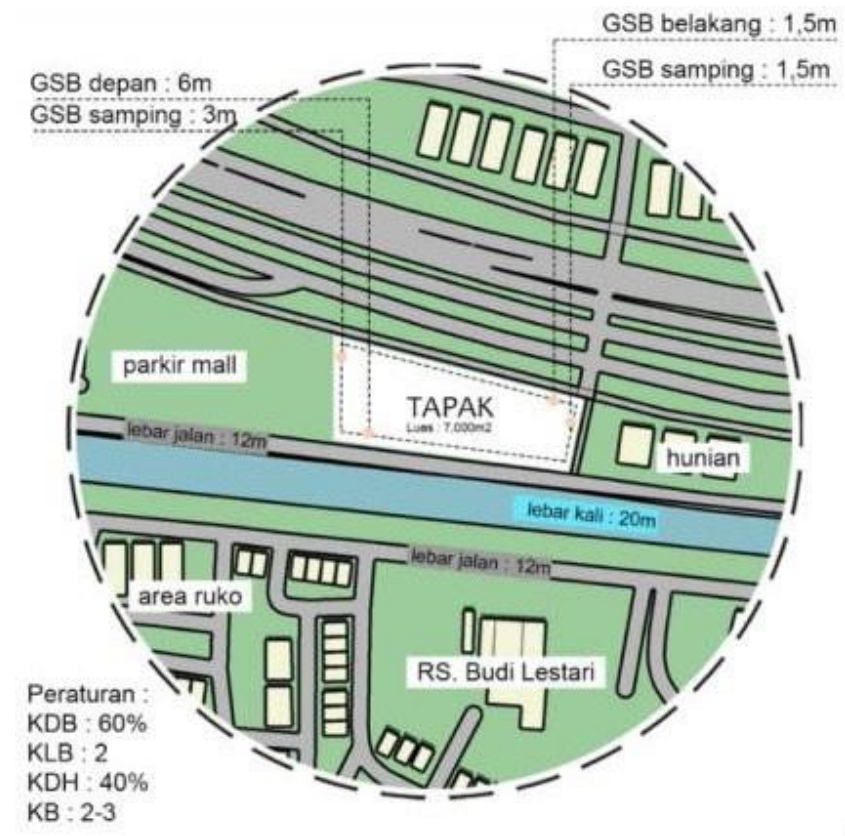

Gambar 3. Ukuran tapak

Sumber: Penulis, 2021

\section{SWOT Analysis}

Tabel 1. Analisa SWOT

\begin{tabular}{cc}
\hline \multicolumn{1}{c}{ Strenght } \\
- dapat dilihat dari segala arah & Weakness \\
- mudah diakses kendaraan & - lingkungan cukup tandus \& \\
- ramah pejalan kaki & dipenuhi polusi asap \\
& - jalan utama diperuntukkan untuk \\
Opportunity & Threat \\
Berada di radius fast fashion terbesar di \\
$\begin{array}{l}\text { Bekasi dan kondisi kota yang selalu sibuk } \\
\text { serta ramai, menjadi peluang untuk } \\
\text { menarik jumlah pengunjung yang tinggi }\end{array}$ & $\begin{array}{c}\text { - berada di radius fast fashion terbesar di } \\
\text { Bekasi, yang bisa menjadi kompetitor bagi } \\
\text { proyek Griya Mode }\end{array}$ \\
\hline
\end{tabular}

Sumber : Pribadi, 2021

\section{Analisis Program Kegiatan}

Gambar di bawah adalah analisis diagramatik dari dua alur pergerakan fesyen untuk proyek yang direncanakan. Pertama adalah alur pengunjung yang menjadi fokus utama mulai dari membeli pakaian, melihat pameran, hingga berpartisipasi dalam kegiatan sirkular fesyen. Kedua adalah pergerakan dari system kapaian bekas, dimana setiap kain yang disumbangkan atau dihasilkan disana melalui proses sirkular berkelanjutan yang tidak berakhir pada satu alur saja. Melainkan setiap produk akan dapat digunakan kembali berdasarkan nilai jual yang dihasilkan dari produk yang diciptakan/diperbaiki oleh komunitas didalamnya. 

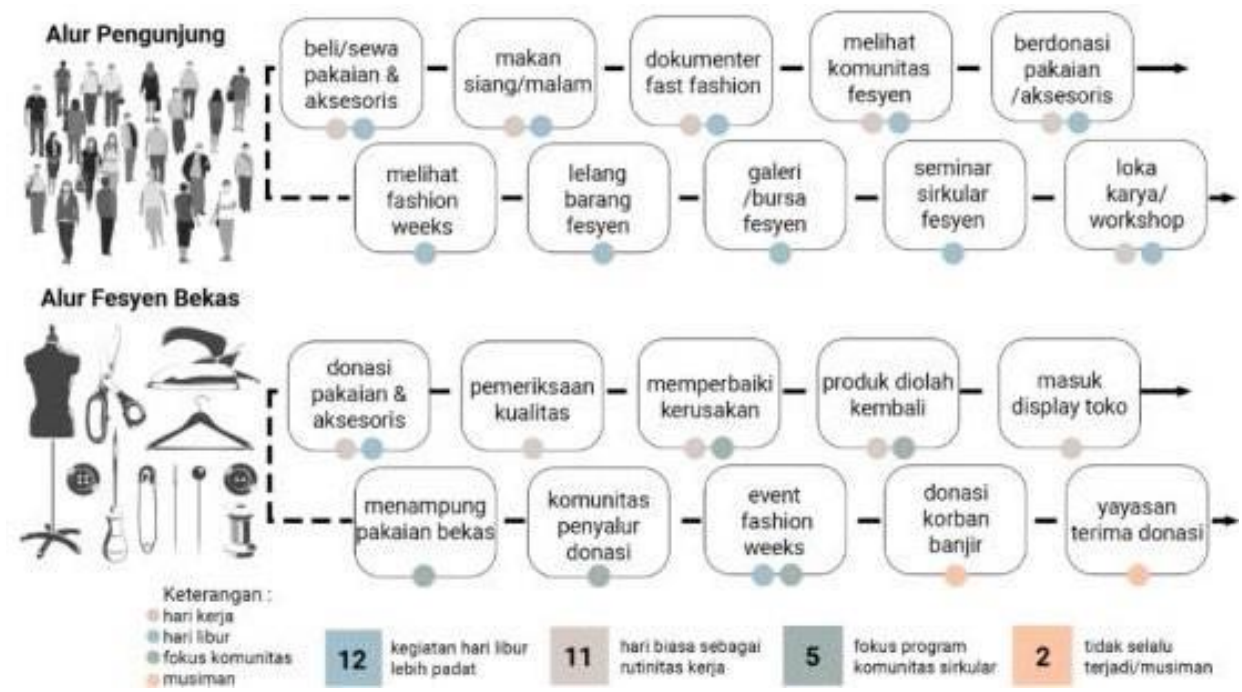

Gambar 4. Penerapan Metode Perancangan Sumber: Penulis, 2021

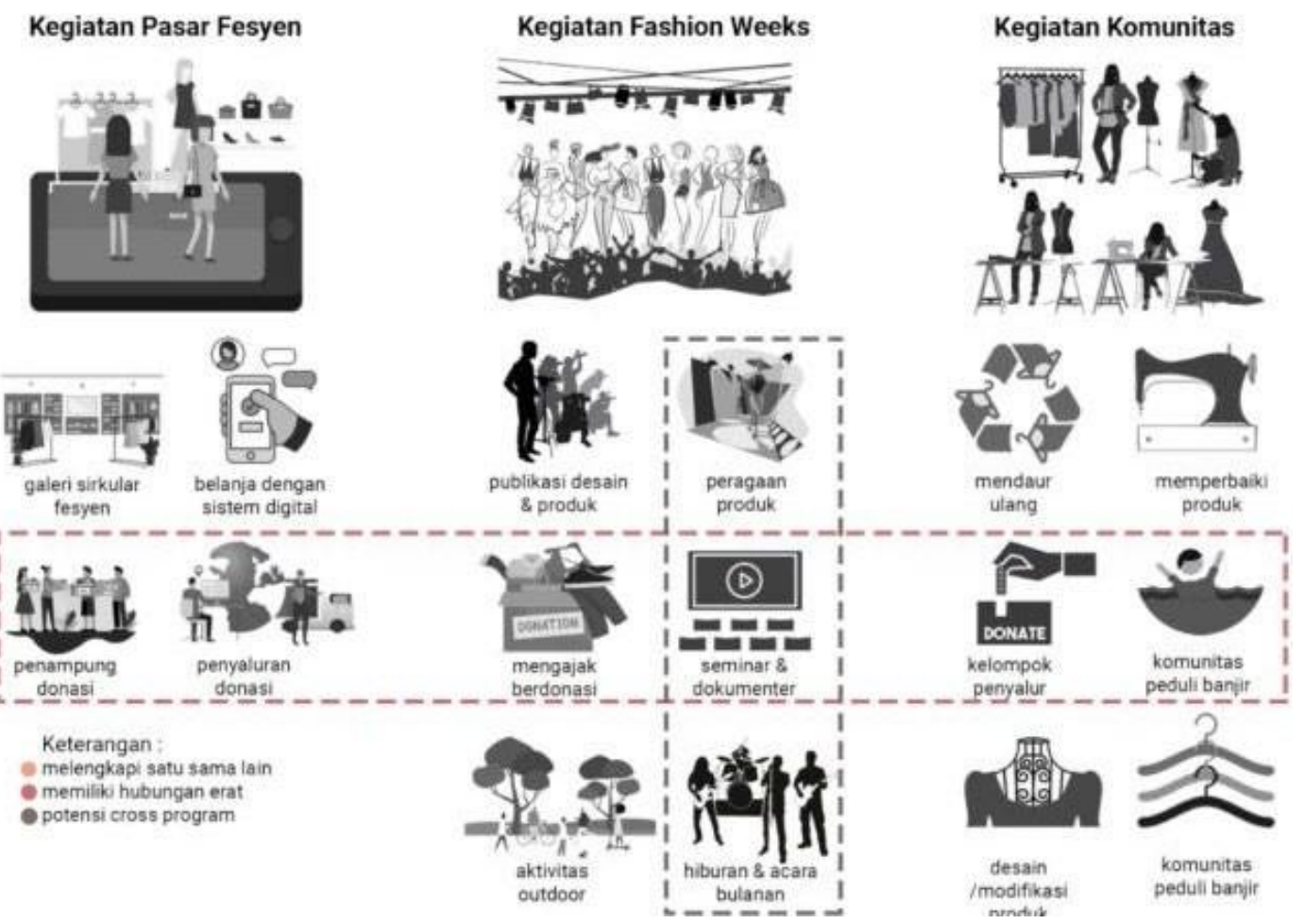

Gambar 5. Penerapan metode perancangan

Sumber: Penulis, 2021 


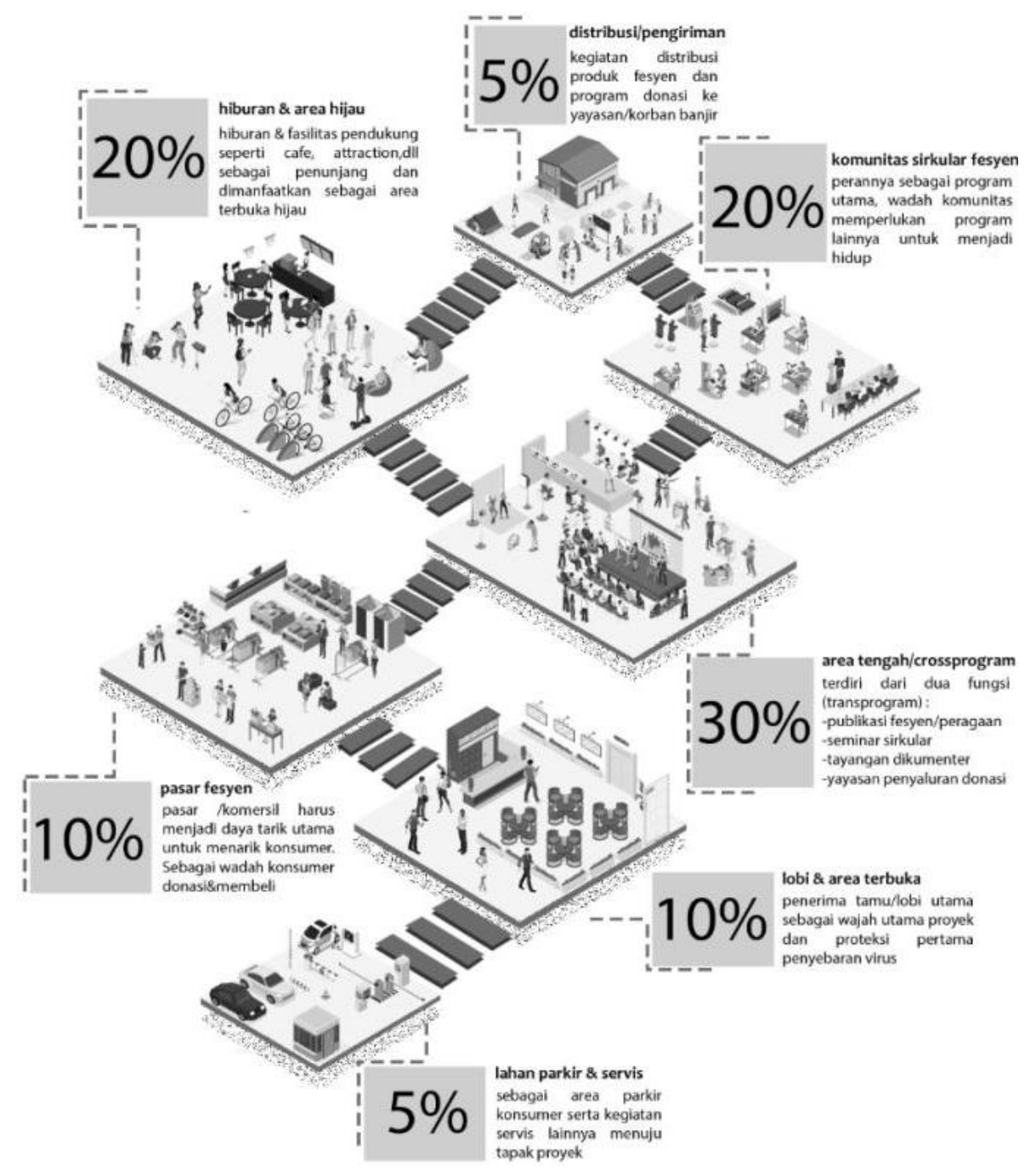

Gambar 6. Penerapan metode perancangan

Sumber: Penulis, 2021

\section{Program Kapasitas dan Konektivitas Bangunan}

Kapasitas proyek Sustainable Fashion Hub didasari oleh 3(tiga) program besar sebagai induk bagi program pendukung lain di belakangnya. Ketiga program ini muncul didasari oleh tujuan dan mimpi utama dalam menciptakan kesuksesan target proyek dalam menanggulangi persoalan krisis fast fashion. Elemen pembentukan programnya digambarkan pada diagram di bawah :
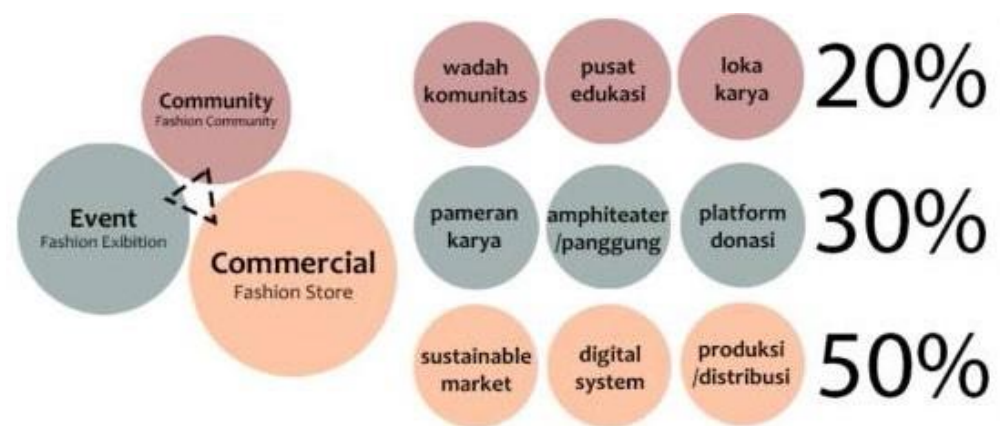

sebagai program utama, komunitas memerlukan program lainnya untuk menjadi hidup

pameran memiliki peran sebagai wadah publikasi \& acara dari program komunitas

program pasar/komersil harus menjadi daya tarik utama untuk menarik konsumer

Gambar 7. Rencana kapasitas bangunan Sumber: Penulis, 2021 


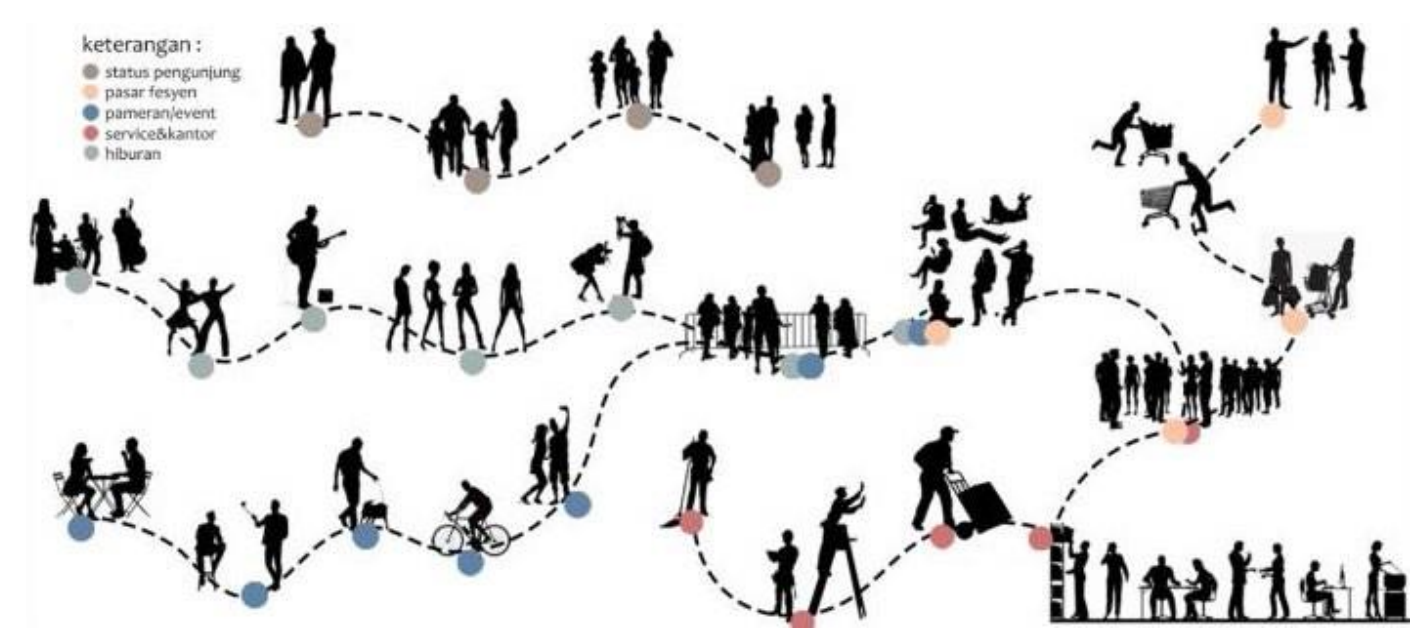

Gambar 8. Rencana koneksi aktivitas pada bangunan

Sumber: Penulis, 2021

Program utama dibagi menjadi 3 kelompok besar menjadi Community, sebagai pusat atau kelompok masyarakat yang bergerak dalam pengelolaan dari berjalannya proyek di dalamnya yang terdiri dari wadah komunitas, pusat edukasi, dan lokakarya sebagai pendukung untuk hidupnya komunitas di dalamnya. Kedua, Events sebagai bentuk dari exhibition untuk karya yang dihasilkan oleh komunitas dan masyarakat sekitar. Program acara ini didukung oleh pameran karya, amphiteater panggung untuk catwalk, serta platform donasi untuk mengajak masyarakat berpartisipasi untuk masyarakat yang membutuhkan seperti korban banjir atau bencana lainnya. Ketiga, wadah commercial, adalah bentuk dari program utama sebagai andalan proyek yang harus menjadi daya tarik utama untuk konsumer. Program induk ini berisikan sustainable market yang berbasis digital system, juga proses produksi distribusi yang aman bagi lingkungan dan berkelanjutan.

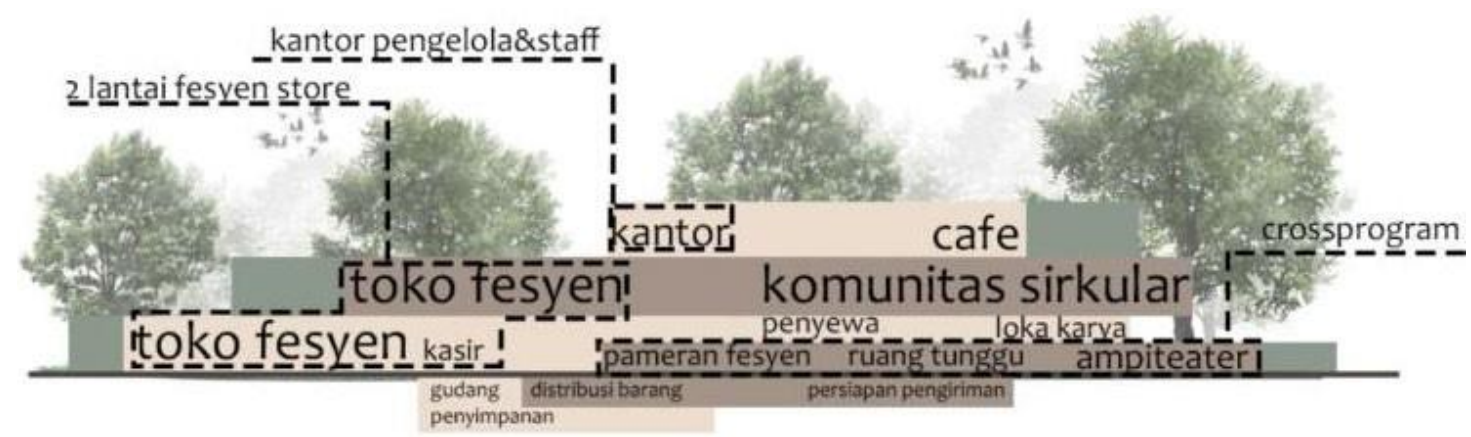

Gambar 9. Konsep Zonasi Pada Bangunan Sumber: Penulis, 2021

Diagram tersebut dikombinasikan dengan standar keruangan arsitektur yang meliputi status pergerakan pengunjung dan area servis sebagai penyokong dari program yang ada. Dari diagram ini, perancang dapat mencari potensi yang menjadi tolak ukur dalam menciptakan program dan pergerakan yang ideal untuk proyek perancangan.

\section{Proses Gubahan Massa}

Keenam gubahan ini adalah urutan pembentukan massa dari penerapan konsepnya. Sebuah visualisasi dari langkah pembetukan massa yang terjadi secara bertahap hingga ke bentuk akhirnya. Langkah perubahan bentuk di bawah juga didasari oleh keadaan tapak, eksistensi karakternya, spatial program utama yang direncanakan, dan lainnya demi menemukan bentuk bangunan yang ideal. 

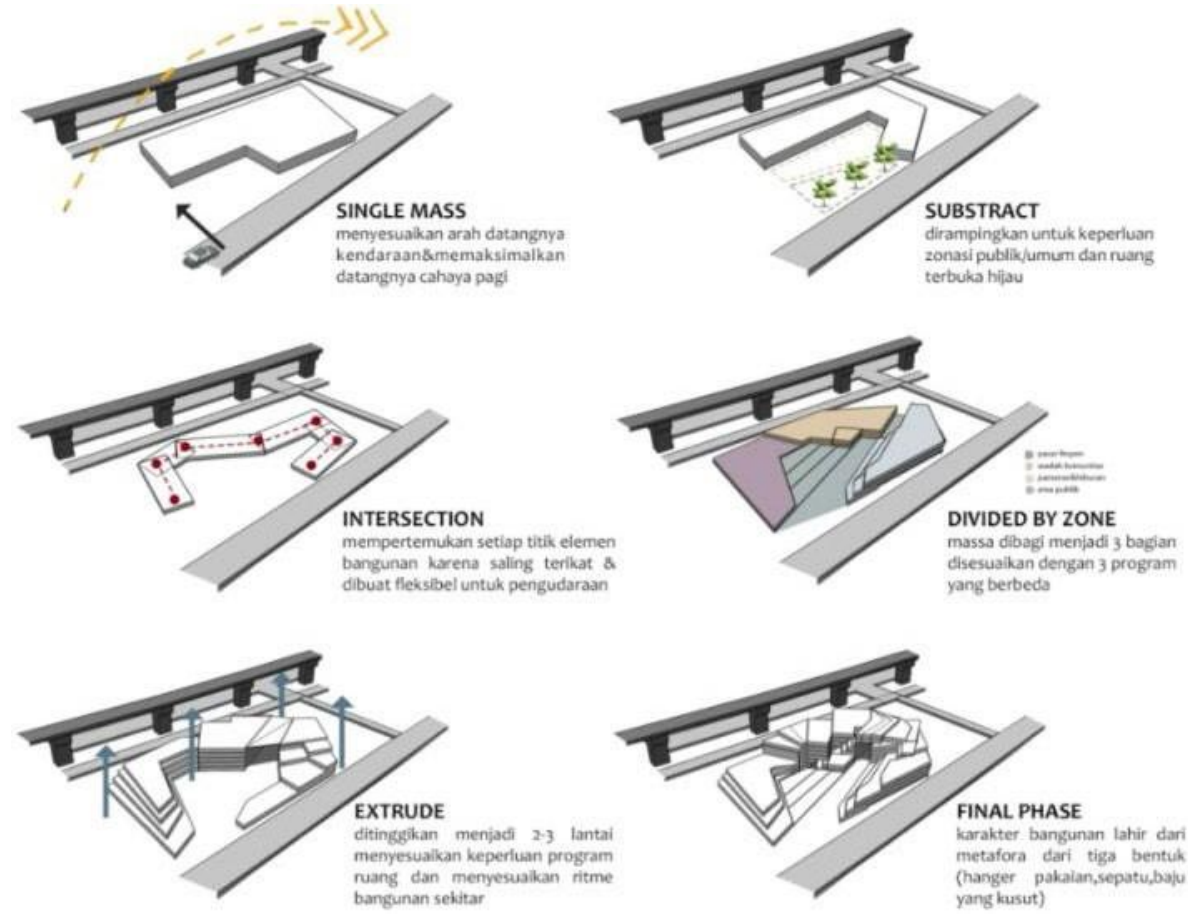

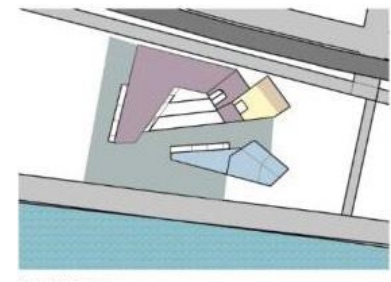

Lantai Dasar

sebagai ruang terbuka/publik untuk rekreasi \& taman sebagai elemen bangunan. Juga kegiatan utama pasar fesyen

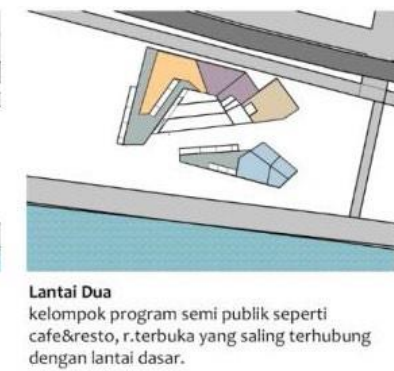

Gambar 10. Zonasi Pada Bangunan

\section{Perhitungan \\ Luasan}

Tabel 2. Tabel Luas Bangunan

\begin{tabular}{cccc}
\hline No. & Massa I & Massa II & R. Terbuka \\
\hline 1 & Pasar Fesyen $\left(700 \mathrm{~m}^{2}\right)$ & Pameran $\left(520 \mathrm{~m}^{2}\right)$ & Penghijauan $\left(4000 \mathrm{~m}^{2}\right)$ \\
\hline 2 & Pengelola \& Komunitas $\left(400 \mathrm{~m}^{2}\right)$ & Catwalk $\left(260 \mathrm{~m}^{2}\right)$ & Area Kumpul $\left(520 \mathrm{~m}^{2}\right)$ \\
\hline 3 & Restoran $\left(350 \mathrm{~m}^{2}\right)$ & Café $\left(285 \mathrm{~m}^{2}\right)$ & Outdoor area \\
\hline
\end{tabular}

Sumber gambar : dokumentasi pribadi, 2021

\section{Konsep Berkelanjutan}

Emission dan energy saving

Menggunakan material yang ramah lingkungan dengan keterbukaan pada sebagian besar eksistensi bangunan. Serta hemat energi listrik karena sifat massa yang cukup transparan.

Technology

Sistem spasial ruang yang dibentuk untuk membangun rasa kepedulian manusia terhadap kerusakan alam akibat dari industri fast fashion melalui pengalaman ruang dan kegiatan didalamnya. Context

Desain perancangan bangunan dengan metode transprogramming yang menimbulkan keterhubungan antar ruang yang saling terikat sehingga setiap sudut ruang memiliki makna. 


\section{Visualisasi proyek}
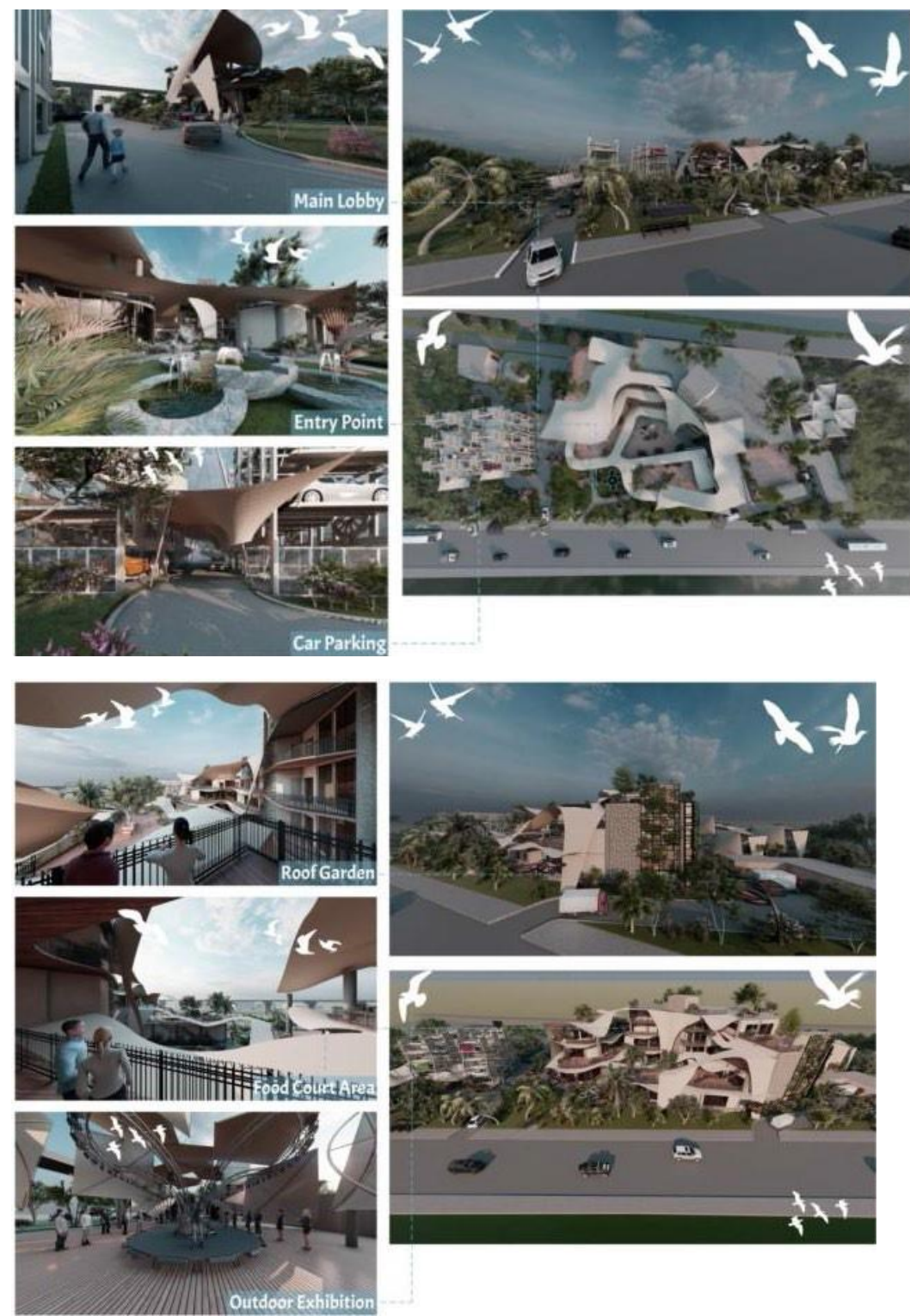

Gambar 12. Perspektif Desain Bangunan Sumber: Penulis, 2021
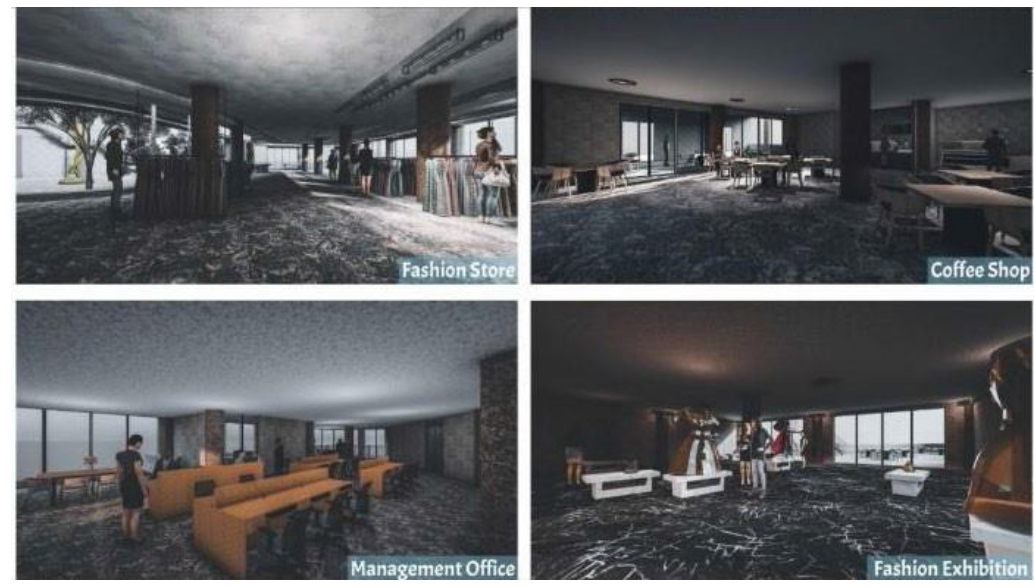

Gambar 13. Perspektif desain ruang dalam bangunan Sumber: Penulis, 2021 


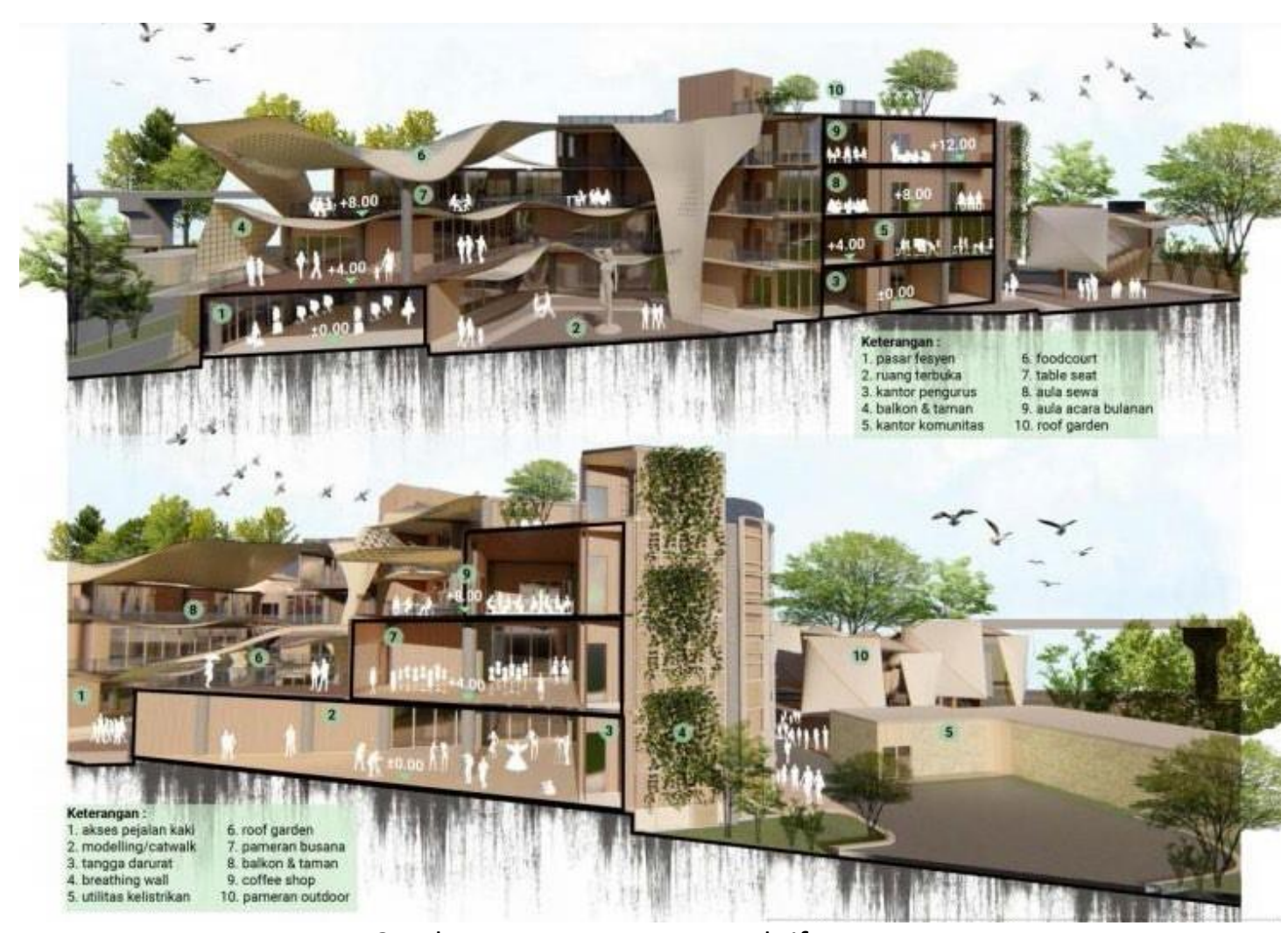

Gambar 14. Potongan perspektif

Sumber: Penulis, 2021

\section{KESIMPULAN DAN SARAN}

\section{Kesimpulan}

Proyek ini bertujuan untuk mengurangi dampak negatif dari industri fesyen yaitu pencemaran lingkungan. Melalui desain bangunan Griya Mode Berkelanjutan yang dihasilkan dalam studi ini dapat disimpulkan bahwa melalui arsitektur dapat diciptakan suatu wadah aktifitas masyarakat penggiat dan konsumen fesyen yang dapat mengurangi dampak negatif industri fesyen terhadap pencemaran lingkungan. Proyek ini diharapkan dapat mengundang orang untuk berpartisipasi dalam mengubah budaya konsumtif dan hedonisme. Menciptakan komunitas yang sadar akan metabolisme gaya hidup yang lebih baik, produktif dan sirkular. Dalam proyek ini, masyarakat dapat menjual dan membeli produk hasil karya komunitas fesyen yang ramah lingkungan, serta berpartisipasi dalam komunitas yang bergerak dalam pelestarian lingkungan melalui teknologi sirkular fesyen juga acara amal untuk penanggulangan bencana di Bekasi.

Saran

Dalam merancang sebuah bangunan bagi kegiatan fesyen yang berkelanjutan, perancang harus memperhatikan standar dari industri yang dihasilkan, kesehatan tiap ruangnya, juga pekerja dan pengunjungnya. Mengingat fast fashion sudah melekat dengan kehidupan masyarakat perkotaan, maka pendekatan yang tepat untuk mengubah perilaku dan persepsi masyarakat tentang fesyen dapat dilakukan dengan menciptakan program fesyen sirkular demi memelihara dan memperbaiki kualitas lingkungan hidup, yang selama ini mengalami penurunan akibat industri fesyen yang kurang berwawasan lingkungan. 


\section{REFERENSI}

Aktas, A. P. (2012). Sustainable Design Proposals in Shopping Center Public Interior. International Journal of Energy and Environtment.

Gissen, D. (2003). Big and Green: Toward Sustainable Architecture in the 21st Century. New York: Princeton Architectural Press .

Levy, M. dan Weitz, B.A., (2008). Retailing Management. 7th ed., Boston: McGraw-Hill/Irwin Sutanto, A, (2021). Dromos-oikos. Kuliah Stupa 8.31. Prodi Arsitektur Universitas Tarumanagara.

Sutanto, A, (2020). Peta Metode Desain. Prodi Arsitektur Universitas Tarumanagara.

Egerton, F. (2013). EgertonHistory of Ecological Sciences, Part 47: Ernst Haeckel's Ecology. https://esajournals.onlinelibrary.wiley.com/doi/full/10.1890/0012-9623-94.3.222

Fairus, S. (2018). Kajian Fast Fashion dalam Percepatan Budaya Konsumerisme https://journals.telkomuniversity.ac.id/rupa/article/view/1329

Jerobisonif, A. (2019). Konsep dan Metode Desain Arsitektur Bernard Tschumi https://ejurnal.undana.ac.id/gewang/article/view/1644

Pratama, M. (2020). Menjamurnya Industri Fast Fashion di Negara Berkembang Meskipun Menimbulkan Berbagai Dampak Negatif https://www.researchgate.net/publication/342513032_Menjamurnya_Industri_Fast_F ashion_di_N egara_Berkembang_Meskipun_Menimbulkan_Berbagai_Dampak_Negatif

Stanford Encyclopedia of Philosophy.2005 https://plato.stanford.edu/entries/ecology/

Tahalele, Y. (2015). Analisa Produk Fesyen Berkelanjutan, Berfield https://webcache.googleusercontent.com/search?q=cache:LLB1tZ00ZoQJ:https://ww w.uc.ac.id/en visi/wp-content/uploads/publikasifpd/ENVISIFPD-2020

Undang-Undang No. 3 Tahun 2014 tentang Perindustrian Tekstil https://www.google.com/url?sa=t\&rct=j\&q=\&esrc=s\&source=web\&cd=\&cad=rja\&uact $=8 \&$ ved $=2$ ahUKEwi80tiC6cTxAhXFWisKHXj2AU8QFnoECBUQAA\&url

Wardana, A. (2014). Definisi Ekologi Arsitektur. arsitek.html.https://alvinwardana.wordpress.com/2014/05/11/definisiekologi/arsitektur 
